\title{
Banquet of Profanities: Food and Subversion in Vera Chytilová's Daisies
}

\author{
Katarina Soukup
}

\begin{abstract}
Dans ce texte, Soukup examine un des films les plus stimulant de la NouvelleVague Tchécoslovaque: Daisies (1966) de Vera Chytilová. Utilisant une analyse du contexte historico-politique de Daisies avec des théories sur le carnavalesque, le corps grotesque et le banquet carnavalesque, Soukup vise à révéler comment la nourriture et la gourmandise dans le film agissent comme métaphores blasphématoires pour transgresser les formes culturelles sanctionnées: à savoir, le canon de la représentation féminine et le réalisme socialiste.
\end{abstract}

One of the most exhilarating cinematic works of the Czechoslovak New Wave is Vera Chytilová's 1966 film, Daisies, the story of two young women who declare the world is spoiled and rotten, and so make a pact that they will be too. They pursue this nasty mission with great relish, involving themselves in a miscellany of adventures, from dining out with numerous Sugar-Daddy fuddy-duddies only to abandon the poor bewildered sods at the train station, to getting rip-roaringly drunk in a cabaret, making a spectacle of themselves and stealing the show. Chytilová's anti-heroines literally devour their world (indeed, the film is replete with images of food and eating), leaving nothing but leftovers, trash and general destruction in their wake.

Evidence of the film's polyvocality, Daisies has been variously interpreted as espousing either condemnation of, or complicity with, capitalist cultural values. For instance, the film has been taken as a critique of capitalist depravity and conspicuous consumption, and the destructive prodigality of the two young women interpreted as the cause of the apocalypse to which the film alludes in the opening and closing credits (Biró 42). ${ }^{1}$ I cannot help but feel, however, that Chytilová and her collaborators (artistic director Esther Krombachová and cinematographer Jaroslav Kucera) take far too much pleasure themselves in the excesses of their Bad Girls to be offering so stern a condemnation. Indeed, this seeming delight in excess 
on Chytilová's part has been detected by other critics, namely Western Marxists of the sixties like filmmaker Jean-Luc Godard, who consequently criticized Chytilová for her "incorrect attitude" and for complicity with bourgeois cultural values (Hames 5).

Neither of these divergent readings, however, does justice to the complexity of Daisies. Chytilová neither denounces nor uncritically reproduces excess, but instead uses it strategically to subvert and destabilize "totalizing regimes" on myriad levels. Thus, Daisies offers ringing critiques of the fate of women in a patriarchal order, the conventions of cinematic narrative, and - read in the context of Czechoslovak politics, history, and culture - Socialist Realism and the Czechoslovakian Communist state. Employing theories of carnival (ranging from those proffered by Russo, Bakhtin, Suleiman, Stallybrass and White), the grotesque body, and Bakhtin's concept of the carnival banquet, I aim to unravel how food and gluttony in Daisies operate as blasphemous metaphors for trangressing sanctioned cultural forms.

\section{Devouring Daisies}

It is as if the carnivalesque body politic had ingested the entire corpus of high culture and, in its bloated and irrepressible state, released it in fits and starts in all manner of recombination, inversion, mockery, and degradation.

- Mary Russo, The Female Grotesque.

Like the carnivalesque body described by Russo, Daisies is a flatulent and blasphemous cinematic corpus which ingests sanctioned cultural forms only to release them in "fits and starts" as a strange, perhaps foul, concoction. Indeed, film critic Claire Clouzot has described the film as "a series of fluctuations between gorging and de-gorging, a come and go between deluxe restaurants and ladies rooms" (qtd. in Quart 223). It is no surprise, then, that in this cyclical and non-linear narrative, food is the dominant structuring principle: the film is practically a non-

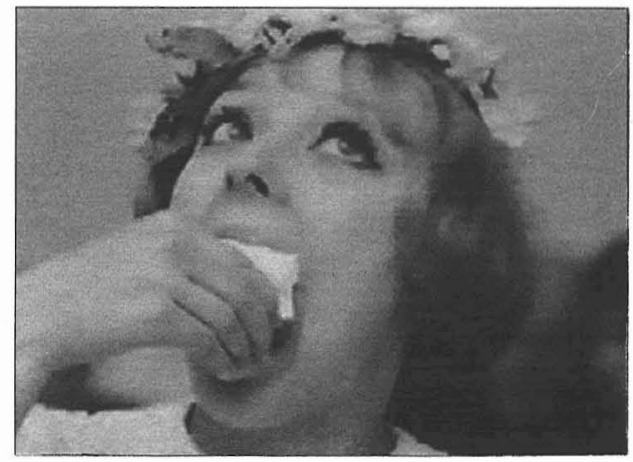


stop pig-out. Green apples (from the Garden of Eden?) tumble through almost every scene, and images associating subversion with food, consumption, ingestion, and gluttony are peppered throughout.

The two protagonists, for example, engage in a series of restaurant escapades involving older gentlemen. The game usually unfolds with the Brunette $^{2}$ alone on a dinner date with an older man - the implied exchange being sexual favours for a meal. The Blonde "suddenly" and "unexpectedly" appears out of nowhere and proceeds to sit herself down at the table. "Oh Jarmilla, what a surprise!" the Brunette says. "Will the lady be eating?" asks the waiter, and before the bewildered man can protest, the Blonde barks: "And she'll be drinking, too!" The waiter suggests a dish, and she petulantly replies, "No that's far too much! I'm hungry for something small." She then proceeds to order a whole chicken ("Is it big enough?") and numerous other dishes, including plates of cakes and pastries and several bowls of soup. When the chicken arrives, she picks the whole bird up in her bare hands and starts gnawing at it. "I so love to eat!" she exclaims. Chytilová uses coloured filters and quick editing to intensify the excessiveness of this binge. One soon realizes that not only is the Blonde devouring a huge meal, but she is eating it in reverse (dessert first, main course last). After both women have been sated at the expense of the elderly gentleman, they rush him off to meet his train at the station ("Is it so late already? My how time flies!"). It is evident that the never-ending parade of food is a tactic for deferring the gentleman's main objective (post-dinner, pre-train hanky-panky) until time runs out.

In another scene, the protagonists are alone at home dressed in nothing but skimpy lingerie. Crêpe paper strips are hanging from the ceiling, lit on fire, while choral music plays. "We're burning!" they shout excitedly as they jump up and down and roast strings of sausages. The phone rings. It is a young Romeo waxing romantic about love: "Is that you Juliet?" he asks. "Yes it's me," they both chime into the receiver. They put down the receiver and resume their feast while Romeo continues his monologue ("I'm always thinking about you..."). Throughout his romantic discourse, they use long surgical scissors and a fork to pick up and ritualistically devour all manner of phallus-shaped foods: sausages, rolls, pickles, bananas (and even a hard-boiled egg for good measure). The castration symbolism - and their attitude towards Romeo - is abundantly clear!

Their ultimate orgy, however, takes place at the end of the film. It begins in black and white. After having made themselves up with thick black 
kohl around the eyes, the pair sneak into a banquet hall laden with delicacies. They are awestruck by the amount of food. Deep timpani drum rolls signal an ominous suspense as they circle the platters like vultures. The Brunette ventures a finger into one dish, and the Blonde slaps her wrist. "No! Carefully, so no one notices!" she says, proceeding to sink all five fingers into a bowl of mashed potatoes. She brings a fistful of food to her mouth and licks: "You see, carefully." The room is filled with the sound of their loudly smacking lips as they flutter from plate to plate. In a close-up of the Brunette eyeing a delicate swan-shaped serving dish, all we see are the black bandit's eyes and the devouring mouth. They sit down at the table, and the Brunette accidentally knocks over a glass. She lets out a yelp, which turns into an orgasmic collage of colour magazine photos of food as a woman's voice cries out rhythmically. They sit in silent shock for a moment. The Brunette examines the broken glass with horror. "Does it really matter?" the Blonde asks. "Of course it doesn't matter," the Brunette replies. Then after a triumphant regalia of trumpets fit for a monarch or military parade, they systematically devour the entire table, moving from

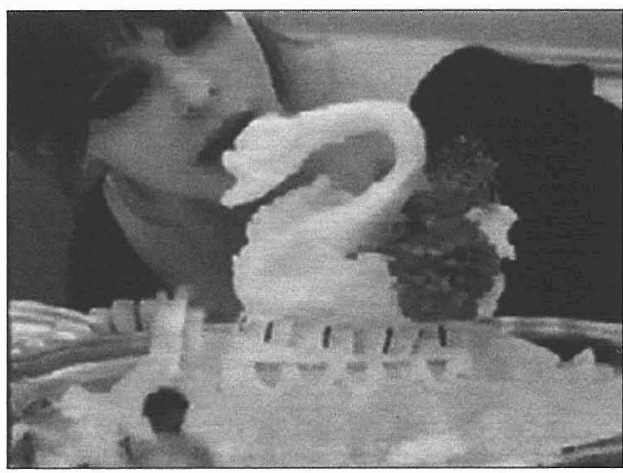
place-sitting to place-sitting. They take one bite from something and throw it behind the chair before moving on to another platter of food. The film has been sped up and they look maniacal in their frenzy to devour everything. They come at last to dessert, and the inevitable food fight starts up over whether the little pastries or the enormous layer cake is tastier. They smash glasses and bottles of liquor and spirits. Utterly everything is destroyed or consumed.

Chytilová's heroines are monstrous man-eating daisies, which are, after all, beautiful flowers whose petals resemble teeth. They are literally cunts with fangs, vaginae dentatae, as the phallic-food scene would indicate. They devour everything in their path, a grotesque exaggeration of stereotypical femininity. Appropriately enough, according to Bakhtin, banquet images (food, drinking, swallowing) are "closely interwoven with those of the grotesque body" and in fact are "one of [its] most significant manifesta- 
tions" $(279,281)$. Emphasizing the open nature of the grotesque body, eating is about the body transgressing its own limits: "it swallows, devours, rends the world apart, [it] is enriched and grows at the world's expense" (281). The mouth becomes the site for ingesting, assimilating, and becoming one with (instead of being Other to) the world. Eating is a means of devouring the world "without being devoured [one]self" (281, my italics). It seems to me that for the two protagonists, eating is deployed precisely in this symbolically strategic way. They devour so as not to be devoured themselves; they eat as a means of partaking in a world that ignores them unless they are displayed as objects of male sexual desire.

Bakhtin writes that food is, literally, a "fruit of labour," the triumph of the body's struggle for survival, and the culmination of collective work; hence, the carnival banquet of medieval times was a collective feast, a banquet "for all the world" (302). With the rise of the bourgeoisie, however, came the privatization of the meal, which was no longer a repast for all but an "intimate feast with beggars at the door" (302). Ironically, and tragically for the Czech people under Communism, a new elite culture established itself despite socialist pretensions of egality. Abundance was to be shared according to Communist dogma, but in reality was dished out only to a select few: high-ranking Party officials. Thus in the final banquet scene of Daisies, the two protagonists subvert the exclusivity, not of bourgeois commensality, but that of elite Party members, for whom the spoils of the table were presumably laid. Sneaking into the dining room after squeezing themselves into a dumb-waiter and peeking through the keyhole, our antiheroines are literally "beggars at the door." Their monstrous gluttony only serves to parody (and thus expose) the gluttony of communist officials. As Eagle maintains,

[t]he destruction of so much food seems gratuitous and horribly wasteful - unless or until we think of the guests for whom it was intended. Could such a small group possibly have eaten all that food? Did they really need it? The characters' (and the director's) gesture of protest against the rich and powerful merely turns elegant conspicuous consumption into the gluttonous spectacle that it actually is. ("Dada" 233)

The grotesque symposium has no respect for hierarchy: "it freely blends the profane and the sacred, the lower and the higher, the spiritual and the 
material" (Bakhtin 286). In Daisies, therefore, we have a commingling of the images of whore and virgin in the final banquet scene. The Blonde wraps a fallen drape over her head and around her body, the virginal garland of daisies circling her temples, while the Brunette peels off her dress and hikes the half-slip over her breasts (a makeshift baby-doll négligé). In this already-profane matrimony of canonical images of femininity, the two carry the blasphemy to even greater heights: accompanied by a sixties surf guitar song, they dance wildly on the banquet table, grinding their highheels into the detritus of their binge.

Judith Butler argues that rules of gender and compulsory heterosexuality are sedimented through a regulated process of resignification, by means of a constant repetition of their performance (145). According to Butler, agency is "located in the possibility of a variation on that repetition" (145, my italics). She argues further that

[i]f the rules governing signification not only restrict, but enable the assertion of alternative domains of cultural intelligibility, i.e. new possibilities for gender that contest the rigid codes of hierarchical binarisms, then it is only within the practices of repetitive signifying that a subversion of identity becomes possible. (145)

A subversive element of Daisies, therefore, lies in its subversive repetition, its blasphemous citation of "intertexts from high and low culture" (Suleiman 161), or "promiscuous textual intercourse" (Mercer 201), especially in the realm of performing femininity. Thus, Daisies renders the monstrous excesses of its protagonists as somehow heroic, while at the same time defiling the symbols of male power and prestige through parody and ridicule. The recombination of high and low texts in Daisies is not only limited to images of femininity. The soundtrack of the film, for instance, is a concoction of incongruous musical styles: raunchy freejazz and rock ' $n$ ' roll ${ }^{3}$ make "promiscuous aural intercourse" with elevated classical, choral, and medieval musics. Fittingly, Eagle notes that the film's intertextual aesthetic invokes the Dada photomontage through its "radical collision of signs from disparate artistic orders" ("Dada" 224).

Such intertextuality creates a condition of heteroglossia, the term Bakhtin uses to describe a multivalent, multilingual, heterogeneous discourse. Heterogeneity has even greater political implications, for as Russo argues, 
"it sets carnival apart from the merely oppositional and reactive. Carnival and the carnivalesque suggest a redeployment or counterproduction of culture, knowledge, and pleasure" (62).

There has been much debate, however, about whether the carnivalesque truly is a revolutionary form provoking such a counterproduction. Some argue that rituals of inversion like carnival act as a mere social safety valve, a "licensed affair ... a permissible rupture of hegemony" sanctioned by ruling interests, which only serve to reinforce the status quo (Eagleton qtd. in Suleiman 143). Thus, such symbolic transgressions are "relatively ineffectual as ... revolutionary work[s] of art" (143). In opposition to this claim, Bakhtin has argued that carnival serves to radically destabilize the order of things: it is not a channeling of unruly energies into innocuous forms, but "revolution itself" (Holquist xviii); an event that transforms the structures and symbols of power. Russo cites Natalie Zemon Davis, for whom carnival rituals in general and the image of the carnivalesque woman in particular "undermine as well as reinforce" (58, my italics) the renewal of the ancien régime. Likewise, Suleiman states that while the con-

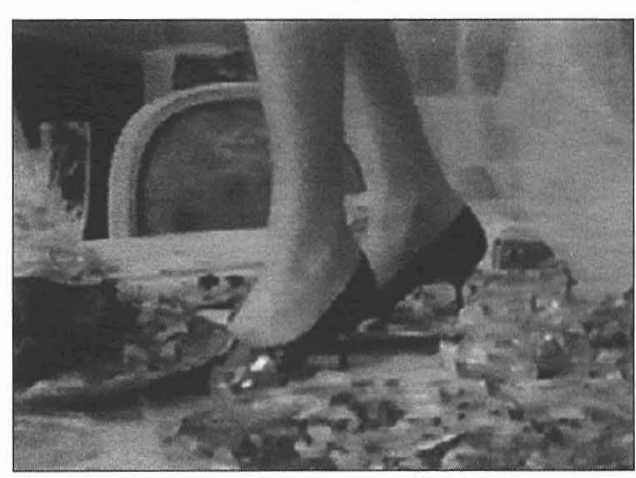
servative view on carnival is right not to overly idealize the emancipatory powers of transgression, it is "too simplistic in its assumption that symbolic modes like carnival ... have no actual, political effects" (143).

According to Suleiman, instances of carnival are neither inherently reifying nor inherently subversive: to understand their effects, such instances must be examined in their specific historical context. Stallybrass and White concur by maintaining that "the politics of carnival cannot be resolved outside of a close historical examination of particular conjunctures" (qtd. in Suleiman 143). According to Suleiman, then, the evaluation of transgressive representations and their "meanings and effects" requires a "finegrained analysis of the relations between context and individual event" (144). It is precisely such a fine-grained analysis that I propose to undertake in unraveling the "meanings and effects" of Vera Chytilová's Daisies as a transgressive and revolutionary work of art. An examination of the cul- 
tural, political, and historical conjuncture in which the film is situated will reveal the full extent of its "counterproduction of culture, knowledge, and pleasure."

\section{Binge and Purge: Socialist Realism Upside-Down}

Socialist Realism, an official state aesthetics imported from the Soviet Union, became enforced in the national cinema of Czechoslovakia (as well as in other Soviet Bloc countries) in 1948, the year marking the beginning of Klement Gottwald's severe Stalinist style of government. Lasting until approximately 1956, with Nikita Kruschev's rise to power in the Soviet Union, this bleak chapter in Czechoslovak history was witness to innumerable Communist Party purges, executions, and imprisonment of thousands of Czechoslovakian citizens. As part of a violent and dogmatic purification of Czechoslovakian culture and society, this era imposed an "official" form of art. Socialist Realism was intended to "represent [...] reality in its revolutionary developments," but in fact simply "amounted to representing historical or contemporary events as the Communist Party wanted them represented" (Eagle, "Czechoslovak" 177). As such, it was more of a discourse of enforced utopia than a genre of "realism"; representing reality not as it was, but "as it w[ould] be" in the revolutionary future (Leong 159).

Daisies was made during the Czechoslovak New Wave, a cinema movement which grew in opposition to Socialist Realism in the years of "deStalinization." As such, it represented a "heightened aesthetic response in a society emerging from a period of enforced cultural orthodoxy" (Hames 8). After the "forced utopia" of Socialist Realism, filmmakers felt a profound need to simply "tell the truth" about the complexities of everyday life: "the grotesque, the tragic, the absurd, death, laughter, conscience, and moral responsibility" (Kosik qtd. in Hames 28). Eagle contends that at every possible opportunity, at every lowered surveillance on the part of the ideological watchdogs of Czech culture, filmmakers were ready to push the "boundaries of permissible cinematic form" ("Czechoslovak" 175). Thus, during the Czechoslovak New Wave, directors dared to "go beyond the limitations of canonical realist style to work in documentary, cinema verité, subjective psychological cinema, overt symbolism, allegory, surrealism, and absurdist cinema" (176).

The first films of the New Wave came out in 1957 and 1958, and contin- 
ued throughout the early and mid-sixties. The audacity of filmmakers increased gradually over these years, in tandem with the slow pace of reforms in social and political arenas during this period of national "selfexamination" culminating in the Prague Spring of 1968. Made in 1966, Daisies can be situated near the latter part of the New Wave, and hence at a relatively more tolerant time in Czechoslovak society, which might account for the fact that its explicit rebelliousness was not quashed by censors during production.

The elevated, official culture which Chytilová's daisies ingest and purge in subversive "fits and starts" is not only the patriarchal canon of feminine representation, or the codes of high art, but also the imposed canon of Socialist Realism. The film is, in fact, a complete inversion and mockery of the conventions of Socialist Realism, wherein a "'positive hero' ... must overcome obstacles in the form of clearly evil ideological antagonists, natural forces, and his or her own lack of developed political consciousness" (Eagle, "Czechoslovak" 177-78). Typically, too, "older mentor figures" (perhaps patriarchs of the Party?) are portrayed as kindly assistants in the awakening of class consciousness in the protagonist (178). Negative characters are also thrown in, of course, and they "battle the forces of humanism and progress seen as inextricably linked to the ... leading role of the Communist Party"; an especially nasty posse of "irredeemable enemies," such as fascists, spies, greedy capitalists, and aristocrats, must be "thwarted or destroyed" while less harmful, but equally misguided figures are reformed and recuperated; converted by the gospel of socialism (178). And like Hollywood, another rigid film canon, ${ }^{4}$ Socialist Realism favours the "happy ending" - of a bright socialist future, that is (Paul 16).

In defiance of the conventions of Socialist Realism, which employs straight-forward styles of representation, Daisies is, first of all, imbued with cinematic excess. It pervades Chytilová's imagery, compositional strategies, and montage. Coloured filters, animation, fragmented montage, alternation between black/white and colour film, and an imaginative use of costume invoke this on a purely visual, stylistic level. The film also subverts the authority of temporal and spatial logic by employing cross cuts, which Eagle has likened to the absurdity, irony, and irrationality of Dada photomontage. Part of the strategy, it seems, for employing this visual play was that even in more liberal periods, filmmakers could not directly or explicitly critique Communist authority, and thus "more condemning conclusions had to be inscribed by subtle stylistic means" 
(Eagle, "Czechoslovak" 181). Irony — "the serenity of gentle destruction" (Biró 37) - is one stylistic mode that Daisies makes ample use of, although it was officially banned by Socialist Realism.

In Daisies the two protagonists are anti-heroes if anything, certainly not imitable models of proper proletarian action and consciousness. In fact, they have no class consciousness, having but fleeting contact with those outside of their intimate boudoir (the Sugar Daddies, the besotted suitor, the lavatory attendant). They are actualized, not by identification with class, but through each other. In one scene, set in their apartment, the two are taking a steaming milk bath together, dipping cookies into the tub and lapping up the milk.

Blonde: "Say, what if someone doesn't exist."

Brunette: "You mean they're dead? Let's assume it's you."

Blonde: "Here we are, sitting here. And now let's say it's not us."

Brunette: "And who says we exist anyway? That you even are?"

Blonde: "But you of course."

Brunette: "Well, precisely. Otherwise, you'd be lost for proof! Listen, you're not working anywhere, you're not registered at this address....

So you see, there's no proof anywhere that you exist."

The dialogue is a sarcastic reference to the strict governmentality and bureaucratic control under Communism, which required a document, certificate, or registration for almost every mundane aspect of life. But it also signals that Chytilová's heroines are women-identified-women, which has prompted some critics to read a lesbian subtext into the film. ${ }^{5}$

The women are most definitely not made in the image of the hard working labourer or farmer favoured in socialist realist epics. They are never shown at work, and most of the time appear idle and bored. Curiously, however, every time they see the lavatory attendant, they proclaim how busy they always are! At one point when they are on a jaunt in the country (symbolically more socialistically pure than the decadent city), they spot the legendary farmer hero one might expect to see in traditional socialist cinema. His mythic status is signaled by the soundtrack which features the angelic voices of spiritual choral music. As he goes about his business, the two protagonists try to gain his attention by cooing like birds, alas to no avail. The true hero of Socialist Realism does not even acknowledge these "misguided" figures. Instead of learning from his vir- 
tuous example, the women return from the countryside with armfuls of stolen corn cobs, which they chew on, spitting out the silk and husks in a trail behind them.

Old men are not "mentors" in Daisies; in fact, far from getting more respect, they are more severely swindled the older they get. Elderly patriarchs are portrayed as comical dim-wits, easily bamboozled by their sexual proclivity for adultery and younger women.

Finally, Chytilová parodies the theme of reform in the socialist realist narrative. The banquet orgy culminates in the pair swinging from a massive chandelier hanging above the table. Perhaps now they have gone too far, been too spoiled, too excessive - a rupture signified in the montage of the film. The chandelier collapses and the film cross cuts to the two girls plunging into a lake, "drowning in the water like two witches" (Miljevic 392). It had to end like this ... is typed across the screen, Could the damage ever be made good? The women scream: "Help! Help! We need help because we're completely spoiled! We don't want to be spoiled anymore!" Even if they were given a chance ... flashes across the screen, it would look something like this....

In the next scene, the two enter the disheveled dining hall dressed in scraps of newspaper wrapped with twine. They make an attempt to "repair" the damage with stiff, robot-like movements, all the while whispering, "we will be good, not spoiled, we will make everything right again, we will be good again. If we are good and work hard we'll be happy and all will be beautiful again." But even this attempt at rehabilitation is patently absurd. They lay out the table settings by piecing together broken plate fragments, sweep the soiled table cloth, and slop the left over food back onto the platters.

At the end of this clean-up, they sit next to each other on the table, surveying their travail:

Blonde (sighing): "We worked so hard! I'm so happy!"

Brunette: "Me too!"

Blonde: "We're both so happy...."

silence

Blonde: "Well, say it, say we're happy!"

Brunette: "But aren't we just playing at it?"

Blonde: "No, because we really are happy."

Brunette: "... but it doesn't really matter." 
Thus, at least for one of them, reform is merely a game, a performance. They lay down, side by side, for a few seconds, in contemplation. Then we see an animated image of the chandelier above them crashing down yet again, with sounds of glass and metal shattering. This segues into images of bombs and aerial explosions and the sound of automatic rifle shots. The film ends with a bizarre epilogue: Dedicated to all those whose indignation is limited to a smashed salad only!

It seems real disaster strikes only after the girls decide to be "good" citizens. As Hames interprets it, conformity to any "official" ideology (be it feminine stereotypes or correct socialist attitudes) which is "based on apathy and lack of conviction, is ultimately more destructive than any of the girls' stupid excesses" (221). The film ends on a decidedly ambiguous note, with no characters clearly branded as evil or virtuous: as Quart has noted, Chytilová seems equivocal about whether "the girls' disorder is a paradigm for the final nuclear destruction; or part of a revolutionary refusal to comply with the order of things" (227).

Not surprisingly, the film troubled Communist officials, for whom Daisies was an "instant catastrophe" (Skvorecky 109). One deputy in the National Assembly had a typically strident socialist bone to pick: he protested the waste of food during the film's production "at a time when our farmers with great difficulties are trying to overcome the problems of our agricultural production" (qtd. in Skvorecky 110). He called for the Minister of the Interior and, absurdly, the Minister of Agriculture to punish Chytilová accordingly for this irreverence. As Skvorecky recalls in his personal memoir of Czechoslovak cinema, "[t]he film was held and shown for the purposes of damnation to selected 'workers'; but they rather liked it, so it was finally released. The force of public opinion was by that time so strong, that not even the President could stop the development" (110).

Interestingly, the film was given an ambiguous, even hostile reception by Western Marxists (Hames 5). Jean-Luc Godard interviewed Chytilová in 1969 and branded her with the following equation: "Chytilová = Zanuck + Paramount" (qtd. in Skvorecky 110). The film was slapped with the label "bourgeois" and derided as a "non-political fantasy" (110). This profound misreading seems to me to be the result of complete ignorance of the sociopolitical context in which Daisies was made, as well as an ignorance of the transgressive potential of the carnivalesque. Apparently, leftists like Godard mistook the elements of carnival in the film for a mere cel- 
ebration of commercial pop culture, completely missing the critique of a totalizing Communist regime and an imposed socialist aesthetic. ${ }^{6}$

\section{From Transgression to Revolution}

As a revolutionary and transgressive work of art, what role did Daisies play in transforming Czech society? Hames, for one, links Daisies and other films of the New Wave to developments in Czechoslovakian society that led to the Prague Spring of 1968. According to him,

[t]he development of creative ideas in the film industry should be seen as one aspect of a wider phenomenon - the growth of ideas in economics, politics, literature, and the arts that made up the Czechoslovak Reform Movement. It was a movement that led directly to the fall of the Novotny regime ${ }^{7}$ and the Action Program of April 1968. (2)

There was growing public approbation for civil rights and political liberalization in Czechoslovakia, even among the highest-ranking Communist Party officials. It was an external interest (the Soviet Union), however, which feared the spread of the "carnival in Bohemia" to other Eastern Bloc countries. Soviet tanks invaded the country on August 21, 1968, effectively reinstating the iron-clad rule of previous Communist governments, despite massive public opposition. Suffering the fate of other cultural institutions in the years following the invasion, the film industry was reigned in, all controversial films were banned (Daisies among them), and the majority of the New Wave filmmakers were silenced (Hames 4). Chytilová's film career was forced into a seven-year hiatus; she only resumed film making in 1976. Since her return to the cinema, she has made over ten films, including a new feature length movie Pasti, pasti, pasticky (1998) released this spring in the Czech Republic. Ever the provocatrice, Chytilová describes the film as a "black, feminist comedy about rape" if such a thing can be imagined!

\section{Conclusion}

Vera Chytilová's Daisies presents us with a banquet of profanities - an ingestion and regurgitation of canonical cultural forms. While her hero- 
ines rip their teeth into the world around them, Chytilová does so symbolically by employing carnivalesque strategies of inversion, intertextuality, and parody. Daisies thus makes a wicked mockery of patriarchal constructions of femininity, and, in the context of Czech history, the imposed aesthetics of Socialist Realism. Beyond this symbolic regurgitation of the Order of Things, Chytilovás film can be situated within a cultural and political movement which led to profound, albeit short-circuited transformations in Czech society. We might then consider her film a revolutionary work of art (Godard notwithstanding) and give it the credit it is due.

\section{Notes}

${ }^{1}$ Barbara Koenig Quart also notes that most superficial critiques of Daisies arrive at this conclusion (222).

2 The names of Chytilová's protagonists constantly change in the film, their identity is never fixed. For this reason, I employ simply "Blonde" and "Brunette" in referring to them.

${ }^{3}$ Two "decadent" musical styles banned by Czechoslovak authorities.

4 "Capitalist" Realism?!

${ }^{5}$ I first saw the film at the 1992 Vancouver Gay and Lesbian Film Festival, where Carla Wolf of Video-In made this argument in a talk entitled "Lesbian Sexual Imagery in Dominant Cinema." In support of this thesis, it's worth noting that in one scene the pair appear to be lounging in a gay bar. The female bartender is suspiciously butch-like, and there is a fleeting close-up shot of two men slow-dancing.

${ }^{6}$ Indeed, the notion of carnival Bakhtin elaborates in Rabelais and his World not only addresses popular resistance in medieval times, but also provides an interpretation of his own society at the time of writing: the Soviet Union in the 1930s, at the height of Stalinism. Thus in this "double-voiced" book, Bakhtin's description of the carnivalesque in the novels of Rabelais is also "a point-by-point inversion of categories used in the thirties to define Socialist Realism" (Holquist xvii).

${ }^{7}$ Novotny was replaced by Alexander Dubcek's reform-minded leadership in January 1968. 


\section{Works Cited}

Bakhtin, Mikhail. Rabelais and His World. Trans. Helene Iswolsky. 1968. Bloomington: Indiana UP, 1984.

Biró, Yvette. "Pathos and Irony in East European Film." Politics, Art and Commitment in the East European Cinema. Ed. David W. Paul. London: Macmillan, 1983. 28-48.

Butler, Judith. Gender Trouble: Feminism and the Subversion of Identity. New York: Routledge, 1990.

Eagle, Herbert. "Czechoslovak, Polish, and Hungarian Cinema under Communism." Cross Currents: A Yearkbook in East and Central European Studies 11 (1992): 175-92.

—. "Dada and Structuralism in Chytilová's Daisies." Cross Currents: A Yearkbook in East and Central European Studies 10 (1991): 223-34.

Hames, Peter. The Czechoslovak New Wave. Berkeley: U of California P, 1985. Holquist, Michael. Prologue. Rabelais and His World. By Mikhail Bakhtin. 1968. Bloomington: Indiana UP, 1984. xiii-xxiii.

Leong, Albert. "Socialist Realism: Cinema and the Arts." Studies in Comparative Communism 17 (1984/85): 157-61.

Mercer, Kobena. Welcome to the Jungle. London: Routledge, Chapman \& Hall, 1994.

Miljevic, Radojka. "Rev. of Daisies, dir. Vera Chytilová." Slavonic and East European Review 73 (1995). 391-3.

Paul, David W. Introduction. Politics, Art and Commitment in the East European Cinema. London: Macmillan, 1983. 1-27.

Quart, Barbara Koenig. Women Directors: The Emergence of a New Cinema. New York: Praeger, 1988.

Russo, Mary. The Female Grotesque: Risk, Excess and Modernity. New York: Duke UP, 1993.

Skvorecky, Josef. All the Bright Young Men and Women: A Personal History of the Czech Cinema. Montreal: Take One and Peter Martin Associates, 1971.

Stallybrass, Peter and Allon White. "Bourgeois Hysteria and the Carnivalesque." The Cultural Studies Reader. Ed. Simon During. London: Routledge, 1993. 284-92.

Suleiman, Susan Rubin. Subversive Intent: Gender, Politics, and the AvantGarde. Cambridge: Harvard UP, 1990. 